\title{
First Record in Brazil of Epistylis sp. (Ciliophora) Adhered to Argulus sp. (Argulidae), a Parasite of Hoplias aimara (Eritrhinidae)
}

\author{
Lincoln Lima Corrêa1*, Marcos Sidney Brito Oliveira ${ }^{2}$, Luiza Prestes ${ }^{3}$, \\ Marcos Tavares-Dias ${ }^{4}$ \\ ${ }^{1}$ Universidade Federal do Oeste do Pará (UFOPA), Instituto de Ciências e Tecnologia das Águas (ICTA), \\ Santarém, Brasil \\ ${ }^{2}$ Programa de Pós-Graduação em Recursos Aquáticos Continentais Amazônicos (PPGRACAM), Universidade \\ Federal do Oeste do Pará (UFOPA), Instituto de Ciências e Tecnologia das Águas (ICTA), Santarém, Brasil \\ ${ }^{3}$ Programa de Pós-Graduação em Ecologia Aquática e Pesca (PPGEAP), Universidade Federal do Pará (UFPA), \\ Belém, Brasil \\ ${ }^{4}$ Embrapa Amapá, Rodovia Juscelino Kubitschek, Macapá, Brasil \\ Email: "lincorre@gmail.com
}

Received 25 April 2016; accepted 10 June 2016; published 13 June 2016

Copyright $@ 2016$ by authors and Scientific Research Publishing Inc.

This work is licensed under the Creative Commons Attribution International License (CC BY).

http://creativecommons.org/licenses/by/4.0/

c) (i) Open Access

\begin{abstract}
This paper records the first occurrence of Epistylis sp. on the body surface of Argulus sp. parasitizing Hoplias aimara from the upper Araguari River, in the eastern Amazon region, in the north of Brazil. Of the 16 specimens of $H$. aimara examined, $93.7 \%$ had their pelvic, caudal and pectoral fins and tegument infested by Argulus sp. $(\mathrm{n}=73)$, which in turn were infested by Epistylis sp. The specimens of Epistylis sp. from the body surface of Argulus sp. were analyzed using Scanning Electron Microscopy (SEM). The present study also identified a widening of the geographic distribution of these two species of ectoparasites to the eastern Amazon region of Brazil.
\end{abstract}

\section{Keywords}

Parasite Ecology, Opportunistic Parasite, Rio Araguari, Eastern Amazon

\footnotetext{
*Corresponding author.
}

How to cite this paper: Corrêa, L.L., Oliveira, M.S.B., Prestes, L. and Tavares-Dias, M. (2016) First Record in Brazil of Epistylis sp. (Ciliophora) Adhered to Argulus sp. (Argulidae), a Parasite of Hoplias aimara (Eritrhinidae). Natural Resources, 7, 331336. http://dx.doi.org/10.4236/nr.2016.76029 


\section{Introduction}

Hoplias aimara Valenciennes, 1847 is a Characiforme from the Erythrinidae family which is distributed from Central America to Argentina, and is popularly known as giant lungfish, lungfish or Aymara. In Brazil, this species is distributed in the Trombeta, Xingu, Tapajós, Jari, Tocantins and Araguari Rivers, as well as the coastal rivers of Surinam and French Guyana [1] [2]. This fish lives in a variety of habitats, from lotic environments such as large rivers and waterfalls to lentic environments such as lakes and reservoirs [3]. However, little is known about the parasites that the fish hosts.

Among Branchiura Thorell, 1818 crustaceans, species of the genus Argulus Müller, 1785 are highly adapted to ectoparasitism in different fish species [4]-[6]. Some Argulus spp. are endemically distributed in the region of the Brazilian Amazon [6]. These ectoparasite crustaceans can reduce the weight, growth rates, breathing capacity, and muscle and fat percentage of fish, and lead to tissue traumatization. The severity of parasitic infection mainly depends on the infestation intensity. When it is high, there may be fish mortality, causing damage to fishing and fish farming [4] [7]-[9].

Species of Epistylis Ehrenberg, 1830 are colony forming ciliates of whom several species are free-living (freshwater and marine) or live in epibiosis, colonizing the body surface of insects and aquatic plants, mollusks, amphibians, reptiles, rotifers and fish. In fish, the main organ colonized is the gills and in Brazil, Epistylis sp. is an emerging parasite [10] [11]. The death of thousands of Centrarchidae in the USA has been attributed to heavy infestation by Epistylis sp., which coincide with ulcers and lesions. As this is not an obligate parasite, these injuries can be gateways to secondary infections, so these mortalities are most often associated with secondary infections caused by bacteria [12] [13]. Epistylis spp. commonly colonizes planktonic copepods [14]-[17]. However, colonization studies of ectoparasite crustaceans are rare [11].

This study describes the first record of Epistylis sp. in Argulus sp. collected from Hoplias aimara, a fish from the upper Araguari River, in the state of Amapá, in the north of Brazil.

\section{Materials and Methods}

A total of 16 specimens of $H$. aimara were collected from a stretch of the Araguari River, in the state of Amapá, Brazil (Figure 1), which is the largest river to be truly located in Amapá, being $617 \mathrm{~km}$ long. Its source is found in the Parque Nacional Montanhas do Tumucumaque (Tumucumaque Mountains National Park), in the Guiana Shield [18]. It passes through the municipalities of Porto Grande and Ferreira Gomes, in the Floresta Nacional do Amapá (Amapá National Forest) (FLONA), the Floresta Estadual do Amapá (Amapá State Forest) (FLOTA) and the Reserva Biológica do Lago Piratuba (Lake Piratuba Biological Reserve) (REBIO), and there are two hydroelectric power plants along its course.

The collection of H. aimara took place in July 2014, using a hand line and gillnet with different mesh sizes. Immediately after capture, the fish were macroscopically examined for the presence of ectoparasite crustaceans. Then, each fish was weighed $(\mathrm{g})$ and its standard length measured $(\mathrm{cm})$. The crustacean specimens collected were fixed in 70\% ethanol before being transferred to $70 \%$ glycerinated alcohol after 48 hours (10\%) and identified in accordance with [8]. The prevalence values, mean abundance and mean intensity were calculated in accordance with [19]. These procedures were carried out in accordance with the principles of the Colégio Brasileiro de Experimento Animal (the Brazilian College of Animal Experimentation) (COBEA).

For analysis with a scanning electron microscope (SEM), five specimens of Argulus sp. previously fixed in $70 \%$ ethanol were transferred to a $2.5 \%$ glutaraldehyde solution in $0.15 \mathrm{M}$ phosphate buffer (pH 7.3) for $24 \mathrm{~h}$, and post-fixed in 1\% osmium tetroxide in the same buffer for $2 \mathrm{~h}$. Dehydration was performed with an increasing sequence of ethanol solutions, and critical point drying was carried out with a CPD 020 (Union Balzer) with liquid $\mathrm{CO}_{2}$. The specimens were coated with a $20 \mathrm{~nm}$ layer of gold using the MED 010 apparatus (Balzer Union). Analysis was performed by SEM (SEM 515 Philips).

\section{Results}

A total of $16 \mathrm{H}$. aimara fish with a body weight of $1619.9 \pm 1054.7 \mathrm{~g}$ and a standard length of $40.7 \pm 9.3 \mathrm{~cm}$ were collected. From these hosts $(n=15)$ a total of 73 specimens of Argulus sp. were collected from the pelvic, caudal and pectoral fins and tegument, with a prevalence of 93.7\%, average intensity of 4.9 host and mean abundance of 4.6. Of these specimens of Argulus sp. five were infested by Epistylis sp., which were adhered in large quantity to the ventral region of the argulidae (Figure 2). 

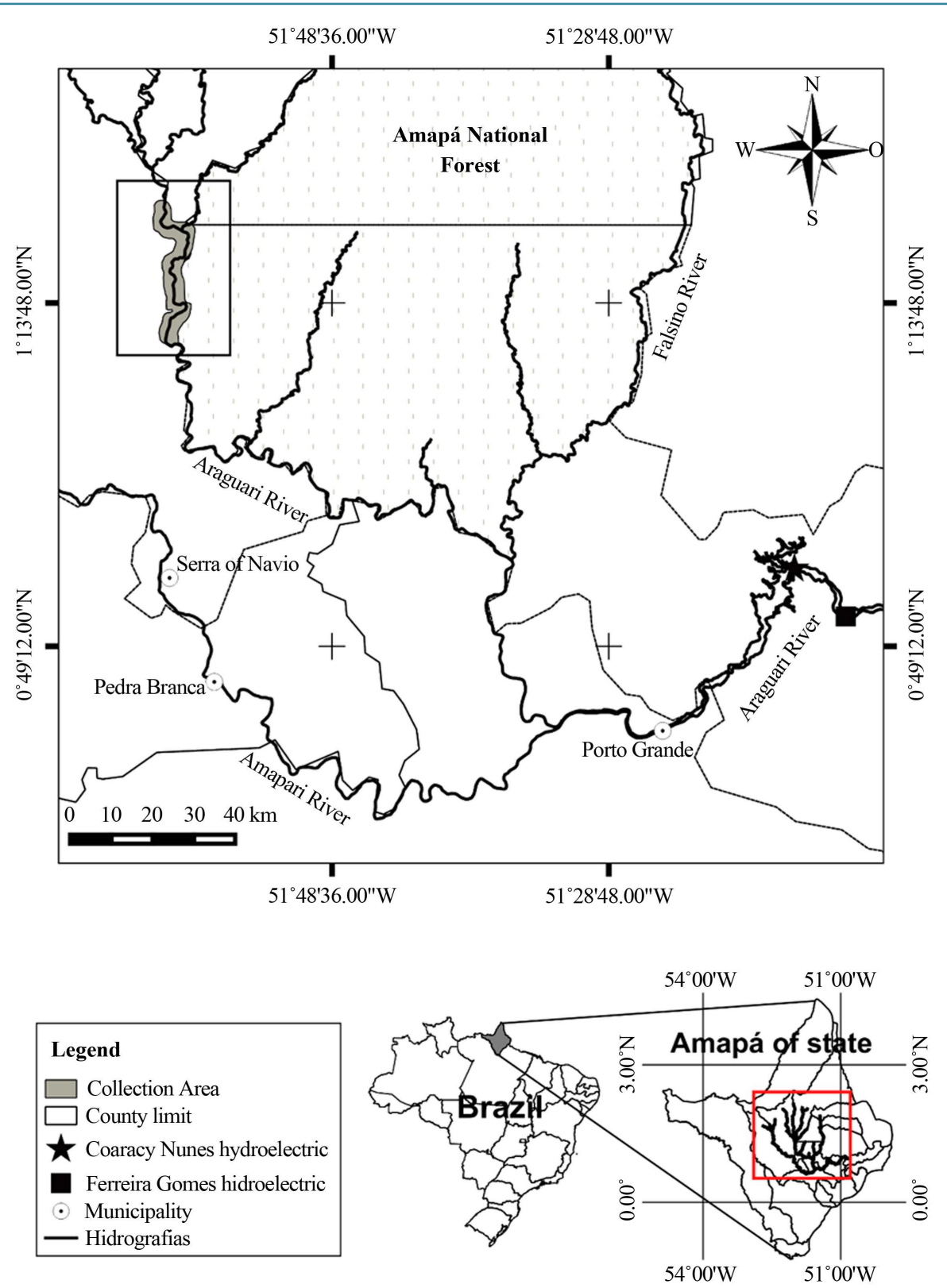

Figure 1. Geographic location of Hoplias aimara collection area in a stretch of the upper Araguari River, in the state of Amapá, in the north of Brazil.

The specimens of Epistylis sp. established themselves on Argulus sp., which in turn serves as a substrate and means of transport, with no lysis or mechanical injury to the infested Argulus sp. observed. The Argulus sp. were infested by Epistylis sp. in various parts of the bodies, with a stalk bearing several zooids (Figure 2A and Figure 2B). This stalk is relatively long and may be divided to form colonies which can be either longer or shorter or more or less ramified (Figure 2B). The vaulted epistomial disc is slightly elevated above the peristomial lips and slanted. The macronuclei are long (Figure 2D).

\section{Discussion}

Hoplias aimara was infested by Argulus sp., which is a new species found parasitizing this host from the Araguari River basin in the state of Amapá (eastern Amazon region, Brazil). Different species of Argulus have been found infesting Brazilian fish, especially species of Anostomidae, Pimelodidae, Cichlidae and Serrasalmidae [6]. 

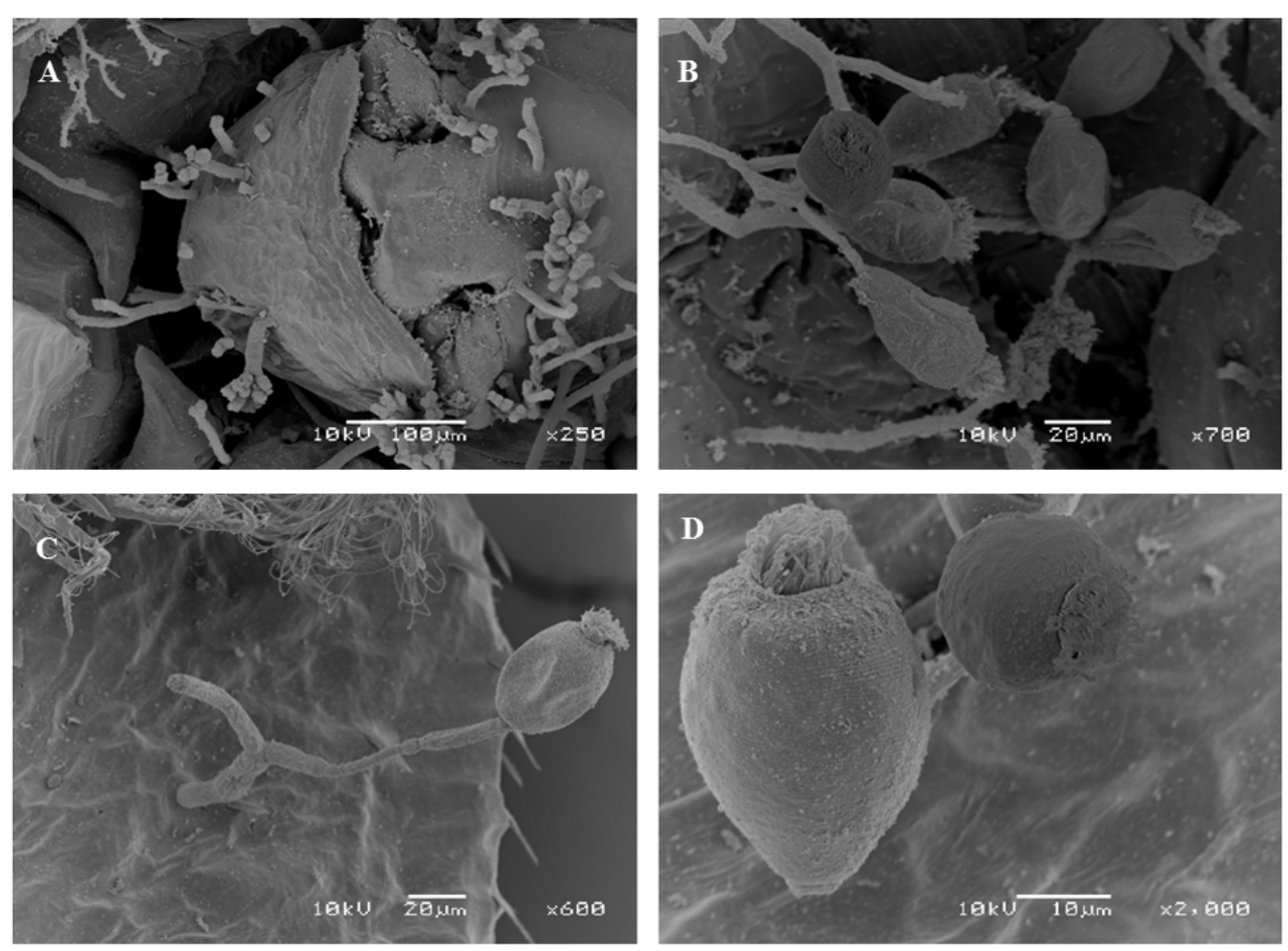

Figure 2. A. Scanning Electron Microscopy (SEM) detailing Epistylis sp. adhered to the anterior region of Argulus sp. B. Extensive and ramified colonies of Epistylis sp. adhered to Argulus sp. C. Epistylis sp. D. Vaulted epistomial disc, slightly elevated above peristomial lips.

These ectoparasites are often found parasitizing the lentic fish environment, as natant-free forms can find their host more easily in such an environment [4] [7] [20]. However, in H. aimara we found a high prevalence of $A r-$ gulus sp., indicating that the infestations also occur in fish from lotic environments, as this host fish also inhabits rapids environments [3], such as the Rio Araguari, the basin of this study. Additionally, the levels of infestation of Argulus sp. in H. aimara were similar to those of Argulus foliaceus described for Cyprinus carpio and Abramis brama [4] and greater than Argulus pestifer in Pseudoplatystoma faciatum [7].

Species of Epistylis are not obligate ectoparasites, but live in epibiosis with shellfish, aquatic plants, rotifers, aquatic insects, amphibians, reptiles, free crustaceans and parasitic crustaceans [10] [11] as has been described for the occurrence of Epistylis sp. in Ergasilus chelangulatus from Pimelodus maculatus [11]. In this manner, the results of the present study suggest that Epistylis sp. also colonizes H. aimara, the fish from which specimens of Argulus sp. were collected. Species of Epistylis have been reported in different species of freshwater fish in Brazil, such as Colisa lalia, Ctenopharyngodon idella, Oreochromis niloticus, Piaractus mesopotamicus, Pseudoplatystoma corruscans, Pseudoplatystoma reticulatum, Leiarius marmoratus, Hemisorubim platyrhynchos and Zungaro jahu [10] [21] [22], which were possibly also infected by crustacean species, suggesting that crustaceans are important for the development and maintenance of the life of Epistylis sp. [11] [14]. Furthermore, it is suggested that the infective forms seek new hosts for the fixation and development of new colonies, such as zooplankton copepods, which can act as vectors or host reservoirs of Epistylis spp., as it is common to find these ciliates fixed on the body surface of copepods [14]-[16] thereby increasing the dissemination of this ciliate.

While Epistylis spp. are considered commensal, this protozoan causes damage such as bodily injury, locomotor disorders, low fertility, reduced competitiveness, increased susceptibility to predation, increased energy demand, faster sinking rates and a decrease in the survival rate to hosts, as well as creating the possibility of bacterial infections [12]-[14] [16]. However, in Argulus sp. parasitizing H. Aymara no injury was found. At the same time, the fixation of Epistylis spp. to fish can result in the proliferation of the parasite, causing depigmentation and injuries to the integument with bleeding issues and the excessive production of mucus, triggering anorexia and itching [21]. Thus, it is suggested that Epistylis spp. is an opportunistic parasite that uses Argulus 
sp. as a substrate and a means of infecting other animals such as H. aimara, which have a greater area for their proliferation.

This first report of Epistylis sp. on the body surface of Argulus sp., in addition to being the first record of $\mathrm{Ar}$ gulus sp. parasitizing H. aimara, extends the geographical distribution of these two species of ectoparasites to the eastern Amazon region in the extreme north of Brazil.

\section{Acknowledgements}

The authors would like to thank Brazil International Conservation (CI), Walmart Brazil, the Instituto Chico Mendes de Conservação da Biodiversidade (ICMBio), and the Biologia e Etnoecologia da Ictiofauna na Floresta Nacional do Amapá (the Biology and Ethno-ecology of the Ichthyofauna of the Amapa National Forest) (FLONA) project for its support. We would also like to thank the fishermen for their help with specimen collection and the evaluators for suggestions that improved the quality of this manuscript, as well as the National Council for Research and Technological Development (CNPq, Brazil), for the productivity scholarship for Dr. Marcos Tavares-Dias.

\section{References}

[1] Planquette, P., Keith, P. and Le Bail, P.-Y. (1996) Atlas des poissons d'eau douce de Guyane: Tome 1. Collection du Patrimoine Naturel, Vol. 22. Service du Patrimoine Naturel/Institut d’Écologie et de Gestion de la Biodiversité/ Muséum National D’histoire Naturelle/Institut National de la Recherche Agronomique/Conseil Supérieur de la Pêche, Paris.

[2] Froese, R. and Rauly, D. (2016) FishBase. World Wide Web Electronic Publication. www.fishbase.org

[3] Oyakawa, O. and Mattox G. (2009) Revision of the Neotropical Trahiras of the Hoplias lacerdae Species Group (Ostariophysi: Characiformes: Erythrinidae) with Descriptions of Two New Species. Neotropical Ichthyology, 7, 117-140. http://dx.doi.org/10.1590/S1679-62252009000200001

[4] Walker, P.D., Harris, J.E., Van der Velde, G. and Wendelaar Bonga, S.E. (2008) Effect of Host Weight on the Distribution of Argulus foliaceus (L.) (Crustacea, Branchiura) within a Fish Community. Acta Parasitologica, 53, 165-172. http://dx.doi.org/10.2478/s11686-008-0020-0

[5] Moller, O.S. (2009) Branchiura (Crustacea)—Survey of Historical Literature and Taxonomy. Arthropod Systematics \& Phylogeny, 67, 41-55.

[6] Tavares-Dias, M., Dias-Júnior, M.B.F., Florentino, A.C., Silva, L.M.A. and Cunha, A.C. (2015) Distribution Pattern of Crustacean Ectoparasites of Freshwater Fish from Brazil. Veterinary Parasitology, 24, 136-147. http://dx.doi.org/10.1590/s1984-29612015036

[7] Malta, J.C.O. (1984) Os peixes de um lago de várzea da Amazônia central (Lago Janauacá, Rio Solimões) e suas relações com os crustáceos ectoparasitos (Branchiura: Argulidae). Acta Amazonica, 14, 355-372. http://dx.doi.org/10.1590/s1984-29612015036

[8] Thatcher, V.E. (2006) Amazon Fish Parasites. 2nd Edition, Pensoft Publishers, Moscow.

[9] Lima, F.S., Casali, G.P. and Takemoto, R.M. (2013) Crustacea. In: Pavanelli, G.C., Takemoto, R.M. and Eiras, J.C., Org., Parasitologia de peixes de água doce do Brasil, Eduem, Maringá, 371-397.

[10] Pádua, S.B., Ishikawa, M.M., Ventura, A.S., Jerônimo, G.T., Martins, M.L. and Tavares, L.E.R. (2013) Brazilian Catfish Parasitized by Epistylis sp. (Ciliophora, Epistylididae), with Description of Parasite Intensity Score. Parasitology Research, 11, 443-446. http://dx.doi.org/10.1007/s00436-012-3069-5

[11] Azevedo, R.K., Brandão, H., Abdallah, V.D. and Silva, R.J. (2014) First Record of an Epibiont Protozoan Epistylis sp. (Ciliophora, Peritrichia) Attached to Ergasilus chelangulatus (Ergasilidae) in Brazil. Brazilian Journal of Biology, 74, 460-463. http://dx.doi.org/10.1590/1519-6984.10112

[12] Rogers, W.A. (1971) Disease in Fish Due to the Protozoan Epistylis (Ciliata: Peritricha) in the Southeastern US. Proceedings of the Southeastern Association of Game Fish Commisioners, 25th Annual Conference, Charleston, 493-496.

[13] Hazen, T.C., Raker, M.L., Esch, G.W. and Fliermans, C.B. (1978) Ultrastructure of Red-Sore Lesions on Largemouth Bass (Micropterus salmoides): Association of the Ciliate Epistylis sp. and the Bacterium Aeromonas hydrophila. Journal of Protozoology, 25, 351-355. http://dx.doi.org/10.1111/j.1550-7408.1978.tb03901.x

[14] Xu, Z. and Burns, C.W. (1991) Effects of the Epizoic Ciliate, Epistylis Duphniae, on Growth, Reproduction and Mortality of Boeckella triarticulata (Thomson) (Copepoda: Calanoida). Hydrobiologia, 209, 183-189. http://dx.doi.org/10.1007/BF00015341

[15] Visse, M. (2007) Detrimental Effect of Peritrich Ciliates (Epistylis sp.) as Epibionts on the Survival of the Copepod 
Acartia bifilosa. Proceedings of the Estonian Academy of Sciences, Biology and Ecology, 56, 173-178.

[16] Bozkurt, A. and Genc, E. (2009) First Record of the Epibiont Protozoan Epistylis sp. on Zooplankton (Copepoda, Cladocera, and Rotifera) from the Asi River, Turkey. Crustaceana, 82, 515-530. http://dx.doi.org/10.1163/156854009X407687

[17] Rajabunizal, K. and Ramanibai, R. (2011) Presence of an Epibiont Epistylis niagarae (Protozoa, Ciliophora) on Mesocyclops aspericornis in Velachery Lake Chennai India. Journal of Biological Sciences, 11, 189-195. http://dx.doi.org/10.3923/jbs.2011.189.195

[18] Cunha, A.C., Vilhena, J.E.S., Santos, E.S., Saraiva, J.M.B., Kuhn, P.A.F., Brito, D.C., Souza, E.B., Rocha, E.P., Cunha, H.F.A., Brito, A.U., Júnior, A.C.P.B., Paca, V.H.M. and Santos, P.V.C.J. (2014) Evento Extremo de chuva-vazão na bacia hidrográfica do Rio Araguari, Amapá, Brasil. Revista Brasileira de Meteorologia, 29, 95-110. http://dx.doi.org/10.1590/0102-778620130051

[19] Bush, A.O., Lafferty, K.D., Lotz, J.M. and Shostack, A.W. (1997) Parasitology Meets Ecology on Its Own Terms: Margolis et al. Revisited. The Journal of Parasitology, 83, 575-583. http://dx.doi.org/10.2307/3284227

[20] Maman, M., Hamel, C. and Van Damme, P.A. (2014) Ectoparasites (Crustacea: Branchiura) of Pseudoplatystoma fasciatum (surubí) and P. tigrinum (Chuncuina) in Bolivian Whitewater Floodplains. Ecología en Bolivia, 39, 9-20.

[21] Pavanelli, G.C., Eiras, J.C. and Takemoto, R.M. (2008) Doença de peixes, profilaxia, diagnóstico e tratamento. 3th Edition, Eduem, Maringá, 311 pp.

[22] Adriano, E.A., Ceccarelli, P.S., Silva, M.R.M. and Maia, A.A.M. (2012) Prevalência, Distribuição geográfica e sazonal de protozoários e mixozoários parasitos de jaú (Zungaro jahu) no Pantanal Matogrossense. Pesquisa Veterinária Brasileira, 32, 1341-1344. http://dx.doi.org/10.1590/S0100-736X2012001200020 